\title{
The Impact of Knowledge Management on Institutional Performance through the Balanced Scorecard-An Applied Study on Ports Training Institution
}

\author{
Rania Mustafa1', Mohamed Wahaba', Alaa El-Gharabawi², Mohamed A. Ragheb1 \\ ${ }^{1}$ The Arab Academy for Science and Technology \& Maritime Transport, Alexandria, Egypt \\ ${ }^{2}$ Faculty of Commerce, Alexandria University, Alexandria, Egypt \\ Email: ron.mos12@yahoo.com, Mwahba@aast.edu,agharabawy@comm.alexu.edu.eg, raghebmm@aast.edu
}

How to cite this paper: Mustafa, R., Wahaba, M., El-Gharabawi, A. and Ragheb, M.A. (2021) The Impact of Knowledge Management on Institutional Performance through the Balanced Scorecard-An Applied Study on Ports Training Institution. Open Access Library Journal, 8: e6997.

https://doi.org/10.4236/oalib.1106997

Received: November 15, 2020

Accepted: January 17, 2021

Published: January 20, 2021

Copyright $\odot 2021$ by author(s) and Open Access Library Inc.

This work is licensed under the Creative Commons Attribution International License (CC BY 4.0).

http://creativecommons.org/licenses/by/4.0/

\section{(c) (i) Open Access}

\begin{abstract}
This study investigates the impact of knowledge management on institutional performance through improving the balanced scorecard. This research depended on the deductive approach to collecting data. The researcher used the method of questionnaires to collect primary data that are used to achieve the purpose of the study, which is to study the effect of knowledge management and balanced scorecard criteria on the institutional performance of the Port Training Institute in Alexandria. The study found that there was a significant relationship between knowledge management and institutional performance.
\end{abstract}

\section{Subject Areas}

Entrepreneurship, Strategic Management, Management Organization

\section{Keywords}

Knowledge Management, the Balanced Scorecard, Institutional Performance, Questionnaires and Deductive Approach

\section{Introduction}

Knowledge is one of the modern assets that organizations possess as "intellectual capital and a value that is realized when invested in real life" [1]. The world today is witnessing many rapid changes in economic, political, social, technological and other events, which affects the business environment surrounding busi- 
ness organizations, as it places them in an inevitable confrontation in front of many challenges, which led to the need to adopt a new approach to work that responds and keeps pace with those challenges and changes represented in knowledge management as a modern method of new management methods that aim to define information, the same value and benefit from it and understand the knowledge assets of the organization.

Knowledge management is a tool for institutions, companies and organizations to invest their intellectual capital and stimulate it to encourage creative capabilities to create new knowledge and pre-disclose problems. Knowledge management contributes to motivating companies, organizations and institutions to renew themselves and face unstable environmental changes. Knowledge management also identifies important resources and critical areas of knowledge to help build several methods that can be used with individuals, groups and with the organization [2].

It is worth noting that most institutions measure their performance using financial reports to assess financial performance in its traditional form, and this of course does not reflect the true image of competition variables in the business environment, which led for the need to use other indicators besides financial indicators to evaluate non-financial performance such as (clients and orientation towards internal operations and growth) and this is what the Balance Score Card did as it is a measurement tool that helps organizations translate their vision and strategy into actions and provides an understandable comprehensive view of organizational performance [3]. For that, the Balanced Scorecard works to improve the institutional performance (financial performance and non-financial performance) of companies, institutions and organizations, and institutions, companies and organizations seek to improve their competitiveness and efficiency, which shows the possibility of activating the Balanced Scorecard in institutions, companies and organizations.

Many previous studies have proven the importance of adopting a knowledge management method in improving the institutional performance of companies, institutions and organizations by accelerating the process of knowledge production, collecting and organizing knowledge of groups and making this knowledge available through participation and data stores, which helps in placing knowledge and skills in the hands of individuals, which leads to the achievement of a higher level of institutional performance for companies and institutions and this is one of the most important goals of any institution or company. Previous studies also confirm that knowledge management has a major effective role on institutional performance as it contributes to the learning process and improves various processes and events by raising levels of efficiency and effectiveness and thus achieving a high and distinguished level of performance. In addition, knowledge management plays an important role in improving the performance of the balanced scorecard, which contributes to improving the performance of institutions, companies and organizations. 


\section{Literature Review}

This section examines the relationship between knowledge management and institutional performance, the relationship between balanced scorecard and knowledge management and the relationship between balanced scorecard and institutional performance through some studies that the researcher has addressed on studying these relationships.

\subsection{The Relationship between Knowledge Management and Institutional Performance}

Many of the current industrial companies are aware of the importance of knowledge management and its dimensions (knowledge creation, knowledge storage, knowledge sharing and knowledge application) and its impact on institutional performance and there are many previous studies that have dealt with the importance of knowledge management for enterprises and how to effectively apply it and make the most of it. In this section, we will deal with some of these studies to prove the role of knowledge management and its importance to institutions.

The relationship between institutional performance and knowledge management was examined [4]. The study methodology was based on collected primary data through questionnaire distributed among 189 managers and employees and the valid data was analyzed to test the study hypothesis (relationship between institutional performance and knowledge management). The results found that knowledge management has a direct impact on institutional performance.

The role of knowledge management on the competitiveness of companies for improving institutional performance was studied [5]. To achieve the aim of the study, the research sample was selected from the database and surveys were made to reach the largest number of organizations at a lower cost. As the results showed a positive relationship between knowledge management and institutional performance.

The relationship between institutional performance and knowledge management for small and medium enterprises (SMES) was investigated [6]. To achieve the study's purpose, the study methodology was built upon collecting data from 30 SMEs in Iran, the study used a questionnaire survey approach to collect data to test the study hypotheses (the relationship between institutional performance and knowledge management for small and medium enterprises), the response rate was $60 \%$, and this data was analyzed. The results of the study concluded that knowledge management has a significant positive impact on the institutional performance of small and medium enterprises (SMES).

The effect of knowledge management on institutional performance was explored [7]. To achieve the objective of the study, a survey was conducted in 14 five-star hotels, in which hotel employees participated in the survey. The results showed the importance of knowledge management on institutional performance. As well as, about the impact of knowledge management on the institutional performance of small and medium-sized companies was investigated [8], 
as a survey was conducted of 277 small and medium-sized companies working in industrial services in Istanbul. Among the most prominent results indicated by the study is the existence of a strong and positive relationship between the level of implementation of knowledge management and institutional performance in companies.

The effect of knowledge management on the institutional performance of the company was clarified [9]. To achieve the aim of the study, a sample survey of high-tech companies in China was conducted and 228 usable responses were collected. The results showed that knowledge management has a significant impact on institutional performance of companies. Moreover, the necessity of using knowledge management for improving institutional performance [10]. To achieve the aim of the study, systematic research was done to study the importance of using knowledge management in organizations to achieve a sustainable competitive advantage and improve the performance of organizations. The results indicated the importance of knowledge management and considered it one of the ways in which institutions can improve organizational performance.

An examination of the relationship between knowledge management and institutional performance and also confirmed that knowledge management helps to improve the various processes and activities within the organization and helps to improve effectiveness, efficiency, creativity and innovation within institutions through many methods [11]. The study methodology was based on the descriptive and analytical method to examine the study hypotheses (the relationship between knowledge management and institutional performance). The results found that knowledge management has a positive effect on institutional performance.

The relationship between knowledge management and institutional performance [12]. The study showed that knowledge management is a set of processes that control, create, spread and use knowledge by a group of practitioners to provide them with the theoretical background of knowledge necessary to improve the types of decisions and their implementation and that knowledge management so, it enhanced the ability of the institution and the organization to maintain and improve institutional performance based on experience and knowledge. In addition, knowledge management worked to motivate institutions to renew themselves in the direction of achieving their goals. The study depended on the descriptive and analytical approach, where the study sample consisted of 68 public works workers and 50 questionnaires were distributed. Only 40 questionnaires were obtained and they were analyzed to examine the study hypothesis (the relationship between knowledge management and institutional performance) using the SPSS program. The results concluded that knowledge management improved institutional performance.

The relationship between institutional performance and knowledge management was investigated [13]. The study methodology followed a systematic review through a combination of questionnaires and a survey. The study findings found that knowledge management has a significant impact on institutional perfor- 
mance. The study of [14] aimed to know the two main components of knowledge management, which are operations and infrastructure and to identify and compare the effects of processes and knowledge management infrastructures on the institutional performance of Malaysian public companies. In order to achieve the aim of the study and reach the results of the study collected data from 176 questionnaires and these data analyzed to examine the study hypothesis. The results indicated that the effect of the knowledge management process is more dominant on the organizational performance than its infrastructure.

The relationship between knowledge management and institutional performance at the College of Applied Studies and Community Service at King Saud University was examined [15]. The study methodology depended on the quantitative method approach through a questionnaire distributed to the employees of the College of Applied Studies and Community Service. The sample size reached 703 from the faculty and the sample used for analysis became 278 questionnaires. The study results that knowledge management has an impact on institutional performance.

The effect of knowledge management on the institutional performance of Shendi textile factory was expound [16]. The study used a questionnaire to collect the primary data. The sample of the study consisted of 35 employees of the International Sur Company (Shendi Textile Factory) and 32 questionnaires were collected, 30 valid forms were analyzed for analysis and the collected data were analyzed using the SPSS program. The results indicated that knowledge management has an impact on institutional performance, as knowledge management enables individuals to achieve the objectives of the organization and enables employees to perform their tasks efficiently and it works to solve the problems facing the institution.

\subsection{The Relationship between Knowledge Management and Balanced Scorecard}

It is worth noting the important role that knowledge management plays in influencing the Balanced Scorecard and thus influencing the institutional performance. There are also many previous studies that aimed to prove that relationship between knowledge management and the balanced scorecard. We will present some of some studies that worked on studying this relationship.

The impact of the practice of knowledge management on performance using the balanced scorecard in medium and small industrial companies was examined [17]. To achieve the aim of the study, data were collected through a questionnaire from a sample of 649 medium and small-sized companies operating in the clothing sector. The results indicated that there is an impact of knowledge management in the use of financial indicators as a dimension of the balanced scorecard. There is also a knowledge management effect in the use of indicators related to internal processes as a dimension of the balanced scorecard. There is also an impact on the use of indicators related to customers as one of the dimensions of the balanced scorecard. In addition, there is an impact of knowledge 
management in the use of indicators related to growth and learning as a dimension of the balanced scorecard. The existence of a knowledge management impact on the use of employee-related indicators as a dimension of the balanced scorecard. Finally, there is a knowledge management effect in the use of environment-related indicators as one of the Balanced Scorecard dimensions.

The effect of knowledge management on the balanced scorecard in Petroerergy Oil and Gas Operations was investigated [18]. The study depended on the descriptive and analytical approach by collecting data from 260 employees in the company through questionnaires distributed among them. The results found that there is a statistical significance between knowledge management and the balanced scorecard.

\subsection{The Relationship between Balanced Scorecard and Institutional Performance}

The balanced scorecard is one of the most important elements that improve the institutional performance of companies and there are many previous studies that have been previously addressed to prove this role of the balanced scorecard in organizations. Some of these studies will be discussed as follows:

The role of the balanced scorecard as a framework for evaluating institutional performance and financial performance of companies was examined [19]. To achieve the aim of the study, a survey was conducted and results indicated that Balanced Scorecard was closely related to financial performance.

The relationship between financial institutional performance and the balanced scorecard in Al-Basr International Charitable Foundation in Sudan was examined [11]. The study collected primary data through questionnaires. The study conclusion indicated that there is a strong direct correlation between the use of the balanced scorecard in Al-Basar International Charitable Foundation in Sudan and the financial performance of the institution.

The possibility of activating the balanced scorecard in improving the financial performance of institutions was investigated [20]. The results found that the Balanced Scorecard improves the financial performance of institutions.

The extent of the impact of the Balanced Scorecard on improving performance in these banks was examined [21]. The study was based on the use of the analytical description method using the questionnaire and among the most prominent results of the study is the existence of a statistically significant relationship between $t$ the Balanced Scorecard and improving the performance of commercial banks in Jeddah.

The effect of the balanced scorecard on the institutional financial performance of small and medium-sized companies was explained [22]. The study methodology was built upon collecting data through questionnaires distributed to 201 small and medium enterprises for the food and beverage industry. The results indicated that companies that use the balanced scorecard get better financial performance, which means that the balanced scorecard improves the financial performance of companies. 


\section{Research Methodology}

In this section, the researcher explains the research methodology adopted in this study. This research depended on the deductive approach to collecting data. The researcher used the method of questionnaires to collect primary data that are used to achieve the purpose of the study, which is to study the effect of knowledge management and balanced scorecard criteria on the institutional performance of the Port Training Institute in Alexandria, which will help the institute to improve his performance with the Balanced Scorecard.

\subsection{Variables and Measurement}

The variables used in this study can be categorized into two main types which are; the dependent and independent variables

\subsubsection{Dependent Variable}

Institutional Performance (Financial Performance and Non-Financial Performance).

\subsubsection{Independent Variable}

Knowledge Management (Knowledge Creation, Knowledge Sharing, Knowledge Application and knowledge Storage).

\subsubsection{Moderating Variables}

Balanced Scorecard (Financial Standards, Customer Perspectives, Internal Operation, Learning and Development).

Figure 1 [23] [24] explains the research framework and identifies the research variables and the research hypotheses as following:

The First Hypothesis: The Relationship between Knowledge Management and Institutional Performance dimensions.

The Second Hypothesis: The Relationship between Knowledge Management and Balanced Scorecard dimensions.

The Third Hypothesis: The Relationship between Balanced Scorecard and Institutional Performance dimensions.

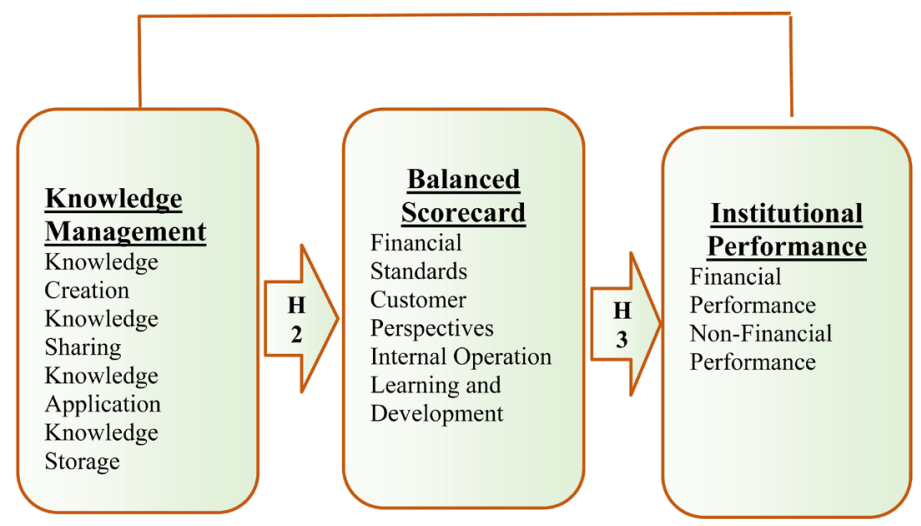

Figure 1. Research framework. 


\section{Research Analysis and Findings}

The researcher in this section will test the hypotheses of the research, which is that there is a moral relationship between research variables and knowledge management practices, and he will analyze the regression between the variables.

\subsection{The First Hypothesis: The Relationship between Knowledge Management and Institutional Performance}

\subsubsection{The First Sub-Hypothesis: The Relationship between Knowledge Management and Financial Performance}

Table 1 shows the correlation matrix for financial performance, it is found that that there is positive significant relationship between knowledge storage and knowledge sharing and financial performance as co-efficient equals to 0.284 and 0.205 respectively with $\mathrm{p}$-value, which is less than 0.05 .

Table 2 shows the regression model for financial performance, it is found that there is positive significant relationship between knowledge storage and financial performance as p-value equals 0.342 , which is less than 0.05 . Financial performance can be explained by knowledge storage as $\mathrm{p}$-value less than 0.05 . While, it is found that there is insignificant relationship between knowledge sharing, knowledge application and knowledge creation and financial performance as p-value more than 0.05 .

Based on the previous results, it can be seen that the first sub-hypothesis of the first hypothesis "There is a statistically significant relationship between knowledge management and financial performance" is partially supported.

Table 1. Correlation matrix of financial performance.

\begin{tabular}{|c|c|c|c|c|c|c|}
\hline & & 1. & 2. & 3. & 4. & 5. \\
\hline \multirow{3}{*}{$\begin{array}{l}\text { Knowledge } \\
\text { Creation }\end{array}$} & Spearman's Correlation & 1.000 & & & & \\
\hline & Sig. (2-tailed) & & & & & \\
\hline & $\mathrm{N}$ & 176 & & & & \\
\hline \multirow{3}{*}{$\begin{array}{l}\text { Knowledge } \\
\text { Storage }\end{array}$} & Spearman's Correlation & $0.586^{\star *}$ & 1.000 & & & \\
\hline & Sig. (2-tailed) & 0.000 & & & & \\
\hline & $\mathrm{N}$ & 176 & 176 & & & \\
\hline \multirow{3}{*}{$\begin{array}{l}\text { Knowledge } \\
\text { Sharing }\end{array}$} & Spearman's Correlation & $0.662^{* *}$ & $0.614^{* *}$ & 1.000 & & \\
\hline & Sig. (2-tailed) & 0.000 & 0.000 & & & \\
\hline & $\mathrm{N}$ & 176 & 176 & 176 & & \\
\hline \multirow{3}{*}{$\begin{array}{l}\text { Knowledge } \\
\text { Application }\end{array}$} & Spearman's Correlation & $0.720^{\star \star}$ & $0.694^{\star *}$ & $0.730^{* *}$ & 1.000 & \\
\hline & Sig. (2-tailed) & 0.000 & 0.000 & 0.000 & & \\
\hline & $\mathrm{N}$ & 176 & 176 & 176 & 176 & \\
\hline \multirow{3}{*}{$\begin{array}{c}\text { Financial } \\
\text { Performance }\end{array}$} & Spearman's Correlation & 0.088 & $0.284^{\star \star}$ & $0.205^{\star *}$ & 0.114 & 1.000 \\
\hline & Sig. (2-tailed) & 0.246 & 0.000 & 0.006 & 0.132 & \\
\hline & $\mathrm{N}$ & 176 & 176 & 176 & 176 & 176 \\
\hline
\end{tabular}


Table 2. The regression model for financial performance.

\begin{tabular}{cccccccc}
\hline \multirow{2}{*}{ Model } & \multicolumn{2}{c}{$\begin{array}{c}\text { Unstandardized } \\
\text { Coefficients }\end{array}$} & $\begin{array}{c}\text { Standardized } \\
\text { Coefficients }\end{array}$ & $\mathbf{t}$ & Sig. & $\begin{array}{c}\text { R } \\
\text { Square }\end{array}$ \\
\cline { 2 - 4 } & B & Std. Error & Beta & & & & \\
\hline (Constant) & 3.006 & 0.280 & & & 10.753 & 0.000 & \\
knowledge creation & -0.145 & 0.096 & -0.156 & -1.507 & 0.134 & \\
knowledge storage & 0.342 & 0.090 & 0.411 & 3.786 & 0.000 & 0.136 \\
Knowledge sharing & 0.162 & 0.099 & 0.187 & 1.629 & 0.105 & \\
Knowledge application & -0.126 & 0.101 & -0.161 & -1.242 & 0.216 & \\
\hline
\end{tabular}

a. Dependent variable: Financial performance.

\subsubsection{The Second Sub-Hypothesis: The Relationship between Knowledge Management and Non-Financial Performance}

Table 3 shows the correlation matrix for non-financial performance, it is found that that there is positive significant relationship between knowledge creation, knowledge application, knowledge storage and knowledge sharing and financial performance as co-efficient equals to $0.626,0.549,0.546$ and 0.624 respectively with p-value, which is less than 0.05 .

Table 4 shows the regression model for non-financial performance, it is found that there is positive significant relationship between knowledge creation and knowledge application and financial performance as p-value equals 0.000 and 0.025 respectively, which is less than 0.05 . Financial performance can be explained by knowledge creation and knowledge application as p-value less than 0.05. While, it is found that there is insignificant relationship between knowledge sharing, knowledge storage and knowledge creation and non-financial performance as p-value more than 0.05 .

Based on the previous results, it can be seen that the second sub-hypothesis of the first hypothesis "There is a statistically significant relationship between knowledge management and non-financial performance" is partially supported. Based on these results, the first hypothesis "there is a statistically significant relationship between knowledge management and institutional performance" is partially supported.

\subsection{The Second Hypothesis: The Relationship between Knowledge Management and Balanced Scorecard}

\subsubsection{The First Sub-Hypothesis: The Relationship between Knowledge Management and Financial Standards}

Table 5 shows the correlation matrix for, it is found that that there is positive significant relationship between knowledge application and knowledge storage and financial standards as co-efficient equals to 0.217 and 0.173 respectively with p-value, which is less than 0.05 .

Table 6 shows the regression model for financial standers, it is found that there is insignificant relationship between knowledge sharing, knowledge storage and knowledge creation and knowledge application and financial standards 
Table 3. Correlation matrix for non-financial performance.

\begin{tabular}{|c|c|c|c|c|c|c|}
\hline & & 1. & 2. & 3. & 4. & 5. \\
\hline \multirow{3}{*}{$\begin{array}{l}\text { knowledge } \\
\text { creation }\end{array}$} & Spearman's Correlation & 1.000 & & & & \\
\hline & Sig. (2-tailed) & & & & & \\
\hline & $\mathrm{N}$ & 176 & & & & \\
\hline \multirow{3}{*}{$\begin{array}{l}\text { knowledge } \\
\text { storage }\end{array}$} & Spearman's Correlation & $0.586^{* *}$ & 1.000 & & & \\
\hline & Sig. (2-tailed) & 0.000 & & & & \\
\hline & $\mathrm{N}$ & 176 & 176 & & & \\
\hline \multirow{3}{*}{$\begin{array}{l}\text { Knowledge } \\
\text { sharing }\end{array}$} & Spearman's Correlation & $0.662^{* *}$ & $0.614^{* *}$ & 1.000 & & \\
\hline & Sig. (2-tailed) & 0.000 & 0.000 & & & \\
\hline & $\mathrm{N}$ & 176 & 176 & 176 & & \\
\hline \multirow{3}{*}{$\begin{array}{l}\text { Knowledge } \\
\text { Application }\end{array}$} & Spearman's Correlation & $0.720^{* *}$ & $0.694^{\star *}$ & $0.730^{\star *}$ & 1.000 & \\
\hline & Sig. (2-tailed) & 0.000 & 0.000 & 0.000 & & \\
\hline & $\mathrm{N}$ & 176 & 176 & 176 & 176 & \\
\hline \multirow{3}{*}{$\begin{array}{l}\text { Non-Financial } \\
\text { Performance }\end{array}$} & Spearman's Correlation & $0.626^{* *}$ & $0.549^{* *}$ & $0.546^{* *}$ & $0.624^{* *}$ & 1.000 \\
\hline & Sig. (2-tailed) & 0.000 & 0.000 & 0.000 & 0.000 & \\
\hline & $\mathrm{N}$ & 176 & 176 & 176 & 176 & 176 \\
\hline
\end{tabular}

Table 4. The regression model for non-financial performance.

\begin{tabular}{cccccccc}
\hline \multirow{2}{*}{ Model } & \multicolumn{2}{c}{$\begin{array}{c}\text { Unstandardized } \\
\text { Coefficients }\end{array}$} & $\begin{array}{c}\text { Standardized } \\
\text { Coefficients }\end{array}$ & $\mathbf{t}$ & Sig. & $\begin{array}{c}\mathbf{R} \\
\text { Square }\end{array}$ \\
\cline { 2 - 5 } & $\mathbf{B}$ & Std. Error & Beta & & & \\
\hline (Constant) & 1.242 & 0.235 & & 5.285 & 0.000 & \\
Knowledge creation & 0.368 & 0.081 & 0.368 & 4.540 & 0.000 & \\
Knowledge Storage & 0.106 & 0.076 & 0.119 & 1.397 & 0.164 & 0.468 \\
Knowledge Sharing & 0.054 & 0.083 & 0.058 & 0.649 & 0.517 & \\
Knowledge Application & 0.193 & 0.085 & 0.230 & 2.264 & 0.025 & \\
\hline
\end{tabular}

a. Dependent variable: Non-financial performance.

Table 5. Correlation matrix for financial standards.

\begin{tabular}{|c|c|c|c|c|c|c|}
\hline & & 1. & 2. & 3. & 4. & 5. \\
\hline \multirow{3}{*}{$\begin{array}{c}\text { Knowledge } \\
\text { Creation }\end{array}$} & Spearman's Correlation & 1.000 & & & & \\
\hline & Sig. (2-tailed) & & & & & \\
\hline & $\mathrm{N}$ & 176 & & & & \\
\hline \multirow{3}{*}{$\begin{array}{l}\text { Knowledge } \\
\text { storage }\end{array}$} & Spearman's Correlation & $0.586^{* *}$ & 1.000 & & & \\
\hline & Sig. (2-tailed) & 0.000 & & & & \\
\hline & $\mathrm{N}$ & 176 & 176 & & & \\
\hline \multirow{3}{*}{$\begin{array}{c}\text { Knowledge } \\
\text { Sharing }\end{array}$} & Spearman's Correlation & $0.662^{\star *}$ & $0.614^{\star *}$ & 1.000 & & \\
\hline & Sig. (2-tailed) & 0.000 & 0.000 & & & \\
\hline & $\mathrm{N}$ & 176 & 176 & 176 & & \\
\hline
\end{tabular}


Continued

\begin{tabular}{lcccccc}
\hline & Spearman's Correlation & $0.720^{* *}$ & $0.694^{* *}$ & $0.730^{* *}$ & 1.000 & \\
$\begin{array}{l}\text { Knowledge } \\
\text { Application }\end{array}$ & Sig. (2-tailed) & 0.000 & 0.000 & 0.000 & & \\
& $\mathrm{~N}$ & 176 & 176 & 176 & 176 & \\
\hline & Spearman's Correlation & 0.127 & $0.217^{* *}$ & $0.173^{*}$ & 0.133 & 1.000 \\
Financial & Sig. (2-tailed) & 0.092 & 0.004 & 0.022 & 0.079 & \\
Standards & $\mathrm{N}$ & 176 & 176 & 176 & 176 & 176 \\
& & & & & & \\
\hline
\end{tabular}

Table 6. The regression model for financial standards.

\begin{tabular}{|c|c|c|c|c|c|c|}
\hline \multirow{2}{*}{ Model } & \multicolumn{2}{|c|}{$\begin{array}{l}\text { Unstandardized } \\
\text { Coefficients }\end{array}$} & \multirow{2}{*}{$\begin{array}{c}\begin{array}{c}\text { Standardized } \\
\text { Coefficients }\end{array} \\
\text { Beta }\end{array}$} & \multirow{2}{*}{$\mathrm{t}$} & \multirow{2}{*}{ Sig. } & \multirow{2}{*}{$\begin{array}{c}\mathbf{R} \\
\text { Square }\end{array}$} \\
\hline & B & Std. Error & & & & \\
\hline (Constant) & 3.183 & 0.223 & & 14.273 & 0.000 & \\
\hline Knowledge creation & 0.036 & 0.077 & 0.051 & 0.469 & 0.640 & \\
\hline Knowledge storage & 0.137 & 0.072 & 0.215 & 1.897 & 0.060 & 0.059 \\
\hline Knowledge sharing & 0.081 & 0.079 & 0.123 & 1.029 & 0.305 & \\
\hline Knowledge application & -0.082 & 0.081 & -0.137 & -1.018 & 0.310 & \\
\hline
\end{tabular}

a. Dependent variable: Financial standards.

as p-value more than 0.05 .

Based on the previous results, it can be seen that the first sub-hypothesis of the second hypothesis "there is a statistically significant relationship between knowledge management and financial standards" is not supported.

\subsubsection{The Second Sub-Hypothesis: The Relationship between Knowledge Management and Customer Perspectives}

Table 7 shows the correlation matrix for customer perspectives, it is found that that there is positive significant relationship between knowledge creation, knowledge sharing, knowledge application and knowledge storage and customer perspectives as co-efficient equals to $0.705,0.613,0.660$ and 0.664 respectively with p-value, which is less than 0.05 .

Table 8 shows the regression model for customer perspectives, it is found that there is positive significant relationship between knowledge creation, knowledge storage and knowledge sharing and customer perspectives as $p$-value is less than 0.05 . Customer perspectives can be explained by knowledge creation, knowledge storage and knowledge sharing as p-value less than 0.05 . While, it is found that there is insignificant relationship knowledge application and customer perspectives as p-value more than 0.05 .

Based on the previous results, it can be seen that the second sub-hypothesis of the second hypothesis "There is a statistically significant relationship between knowledge management and the customer perspectives" is partially supported. 
Table 7. The correlation matrix for customer perspectives.

\begin{tabular}{|c|c|c|c|c|c|c|}
\hline & & 1. & 2. & 3. & 4. & 5. \\
\hline \multirow{3}{*}{$\begin{array}{l}\text { Knowledge } \\
\text { creation }\end{array}$} & Spearman's Correlation & 1.000 & & & & \\
\hline & Sig. (2-tailed) & & & & & \\
\hline & $\mathrm{N}$ & 176 & & & & \\
\hline \multirow{3}{*}{$\begin{array}{l}\text { Knowledge } \\
\text { storage }\end{array}$} & Spearman's Correlation & $0.586^{\star *}$ & 1.000 & & & \\
\hline & Sig. (2-tailed) & 0.000 & & & & \\
\hline & $\mathrm{N}$ & 176 & 176 & & & \\
\hline \multirow{3}{*}{$\begin{array}{l}\text { Knowledge } \\
\text { sharing }\end{array}$} & Spearman's Correlation & $0.662^{\star *}$ & $0.614^{* *}$ & 1.000 & & \\
\hline & Sig. (2-tailed) & 0.000 & 0.000 & & & \\
\hline & $\mathrm{N}$ & 176 & 176 & 176 & & \\
\hline \multirow{3}{*}{$\begin{array}{l}\text { Knowledge } \\
\text { application }\end{array}$} & Spearman's Correlation & $0.720^{* *}$ & $0.694^{* *}$ & $0.730^{* *}$ & 1.000 & \\
\hline & Sig. (2-tailed) & 0.000 & 0.000 & 0.000 & & \\
\hline & $\mathrm{N}$ & 176 & 176 & 176 & 176 & \\
\hline \multirow{3}{*}{$\begin{array}{l}\text { Customer } \\
\text { perspectives }\end{array}$} & Spearman's Correlation & $0.705^{\star *}$ & $0.613^{* *}$ & $0.660^{* *}$ & $0.664^{\star *}$ & 1.000 \\
\hline & Sig. (2-tailed) & 0.000 & 0.000 & 0.000 & 0.000 & \\
\hline & $\mathrm{N}$ & 176 & 176 & 176 & 176 & 176 \\
\hline
\end{tabular}

Table 8. The regression model for customer perspectives.

\begin{tabular}{cccccccc}
\hline \multirow{2}{*}{ Model } & \multicolumn{2}{c}{$\begin{array}{c}\text { Unstandardized } \\
\text { Coefficients }\end{array}$} & $\begin{array}{c}\text { Standardized } \\
\text { Coefficients }\end{array}$ & $\mathbf{t}$ & Sig. & $\begin{array}{c}\mathbf{R} \\
\text { Square }\end{array}$ \\
\cline { 2 - 4 } & B & Std. Error & Beta & & & \\
\hline (Constant) & 0.670 & 0.213 & & 3.139 & 0.002 & \\
Knowledge creation & 0.396 & 0.074 & 0.387 & 5.380 & 0.000 & \\
Knowledge storage & 0.194 & 0.069 & 0.212 & 2.802 & 0.006 & 0.581 \\
Knowledge Sharing & 0.243 & 0.076 & 0.256 & 3.210 & 0.002 & \\
Knowledge Application & 0.019 & 0.077 & 0.022 & 0.240 & 0.811 & \\
\hline
\end{tabular}

a. Dependent variable: Customer perspectives.

\subsubsection{The Third Sub-Hypothesis: The Relationship between Knowledge Management and Internal Operations}

Table 9 shows the correlation matrix for internal operations, it is found that that there is positive significant relationship between knowledge creation, knowledge sharing, knowledge application and knowledge storage and customer perspectives as co-efficient equals to $0.683,0.601,0.680$ respectively with p-value, which is less than 0.05 .

Table 10 shows the regression model for internal operation, it is found that there is positive significant relationship between knowledge creation, knowledge storage and knowledge sharing and internal operation as p-value is less than 0.05 . Internal operation can be explained by knowledge creation, knowledge storage and knowledge sharing as p-value less than 0.05 . While, it is found that 
Table 9. Correlation matrix for internal operation.

\begin{tabular}{|c|c|c|c|c|c|c|}
\hline & & 1. & 2. & 3. & 4. & 5. \\
\hline \multirow{3}{*}{$\begin{array}{l}\text { Knowledge } \\
\text { creation }\end{array}$} & Spearman's Correlation & 1.000 & & & & \\
\hline & Sig. (2-tailed) & & & & & \\
\hline & $\mathrm{N}$ & 176 & & & & \\
\hline \multirow{3}{*}{$\begin{array}{l}\text { Knowledge } \\
\text { storage }\end{array}$} & Spearman's Correlation & $0.586^{* *}$ & 1.000 & & & \\
\hline & Sig. (2-tailed) & 0.000 & & & & \\
\hline & $\mathrm{N}$ & 176 & 176 & & & \\
\hline \multirow{3}{*}{$\begin{array}{l}\text { Knowledge } \\
\text { sharing }\end{array}$} & Spearman's Correlation & $0.662^{\star *}$ & $0.614^{* *}$ & 1.000 & & \\
\hline & Sig. (2-tailed) & 0.000 & 0.000 & & & \\
\hline & $\mathrm{N}$ & 176 & 176 & 176 & & \\
\hline \multirow{3}{*}{$\begin{array}{l}\text { Knowledge } \\
\text { Application }\end{array}$} & Spearman's Correlation & $0.720^{* *}$ & $0.694^{* *}$ & $0.730^{* *}$ & 1.000 & \\
\hline & Sig. (2-tailed) & 0.000 & 0.000 & 0.000 & & \\
\hline & $\mathrm{N}$ & 176 & 176 & 176 & 176 & \\
\hline \multirow{3}{*}{$\begin{array}{l}\text { Internal } \\
\text { Operation }\end{array}$} & Spearman's Correlation & $0.683^{\star *}$ & $0.601^{\star *}$ & $0.672^{\star *}$ & $0.680^{\star *}$ & 1.000 \\
\hline & Sig. (2-tailed) & 0.000 & 0.000 & 0.000 & 0.000 & \\
\hline & $\mathrm{N}$ & 176 & 176 & 176 & 176 & 176 \\
\hline
\end{tabular}

Table 10. The regression model for internal operation.

\begin{tabular}{|c|c|c|c|c|c|c|}
\hline \multirow[t]{2}{*}{ Model } & \multicolumn{2}{|c|}{$\begin{array}{l}\text { Unstandardized } \\
\text { Coefficients }\end{array}$} & \multirow{2}{*}{$\begin{array}{c}\begin{array}{c}\text { Standardized } \\
\text { Coefficients }\end{array} \\
\text { Beta }\end{array}$} & \multirow[t]{2}{*}{$\mathrm{t}$} & \multirow[t]{2}{*}{ Sig. } & \multirow{2}{*}{$\begin{array}{c}\mathbf{R} \\
\text { Square }\end{array}$} \\
\hline & B & Std. Error & & & & \\
\hline (Constant) & 0.595 & 0.199 & & 2.987 & 0.003 & \\
\hline Knowledge creation & 0.372 & 0.069 & 0.364 & 5.416 & 0.000 & \\
\hline Knowledge storage & 0.146 & 0.065 & 0.160 & 2.265 & 0.025 & 0.635 \\
\hline Knowledge sharing & 0.249 & 0.071 & 0.262 & 3.524 & 0.001 & \\
\hline Knowledge Application & 0.111 & 0.072 & 0.129 & 1.531 & 0.128 & \\
\hline
\end{tabular}

a. Dependent variable: Internal operation.

there is insignificant relationship knowledge application and internal operation as p-value more than 0.05 .

Based on the previous results, it can be seen that the third sub-hypothesis of the second hypothesis "There is a statistically significant relationship between knowledge management and internal operations" is partially supported.

\subsubsection{The Forth Sub-Hypothesis: The Relationship between Knowledge Management and Learning and Development}

Table 11 shows the correlation matrix for learning and development, it is found that that there is positive significant relationship between knowledge creation, knowledge sharing, knowledge application and knowledge storage and customer perspectives as co-efficient equals $0.581,0.517,0.683$ and 0.640 respectively with $\mathrm{p}$-value, which is less than 0.05 . 
Table 11. The correlation matrix for learning and development.

\begin{tabular}{|c|c|c|c|c|c|c|}
\hline & & 1. & 2. & 3. & 4. & 5. \\
\hline \multirow{3}{*}{$\begin{array}{l}\text { Knowledge } \\
\text { creation }\end{array}$} & Spearman's Correlation & 1.000 & & & & \\
\hline & Sig. (2-tailed) & & & & & \\
\hline & $\mathrm{N}$ & 176 & & & & \\
\hline \multirow{3}{*}{$\begin{array}{l}\text { Knowledge } \\
\text { storage }\end{array}$} & Spearman's Correlation & $0.586^{* *}$ & 1.000 & & & \\
\hline & Sig. (2-tailed) & 0.000 & & & & \\
\hline & $\mathrm{N}$ & 176 & 176 & & & \\
\hline \multirow{3}{*}{$\begin{array}{l}\text { Knowledge } \\
\text { sharing }\end{array}$} & Spearman's Correlation & $0.662^{* *}$ & $0.614^{\star *}$ & 1.000 & & \\
\hline & Sig. (2-tailed) & 0.000 & 0.000 & & & \\
\hline & $\mathrm{N}$ & 176 & 176 & 176 & & \\
\hline \multirow{3}{*}{$\begin{array}{l}\text { Knowledge } \\
\text { Application }\end{array}$} & Spearman's Correlation & $0.720^{* *}$ & $0.694^{\star *}$ & $0.730^{* *}$ & 1.000 & \\
\hline & Sig. (2-tailed) & 0.000 & 0.000 & 0.000 & & \\
\hline & $\mathrm{N}$ & 176 & 176 & 176 & 176 & \\
\hline \multirow{3}{*}{$\begin{array}{l}\text { Learning and } \\
\text { Development }\end{array}$} & Spearman's Correlation & $0.581^{* *}$ & $0.517^{\star *}$ & $0.683^{* *}$ & $0.640^{* *}$ & 1.000 \\
\hline & Sig. (2-tailed) & 0.000 & 0.000 & 0.000 & 0.000 & \\
\hline & $\mathrm{N}$ & 176 & 176 & 176 & 176 & 176 \\
\hline
\end{tabular}

Table 12 shows the regression model for learning and development, it is found that there is positive significant relationship between knowledge application and knowledge sharing and internal operation as p-value is less than 0.05. Internal operation can be explained by knowledge application and knowledge sharing as p-value less than 0.05 . While, it is found that there is insignificant relationship between knowledge creation and knowledge storage and internal operation as p-value more than 0.05 .

Based on the previous results, it can be seen that the fourth sub-hypothesis of the second hypothesis "There is a statistically significant relationship between knowledge management and learning and development" is partially supported. Based on these results, the second hypothesis "there is a statistically significant relationship between knowledge management and the balanced scorecard" is partially supported.

\subsection{The Third Hypothesis: The Relationship between Balanced Scorecard and Institutional Performance}

\subsubsection{The First Sub-Hypothesis: The Relationship between Balanced Scorecard and Financial Performance}

Table 13 shows the correlation matrix for financial performance, it is found that that there is positive significant relationship between financial standards, internal operation and learning and development and financial performance as co-efficient equals $0.630,0.189$ and 0.190 respectively with $p$-value, which is less than 0.05 .

Table 14 shows the regression model for financial performance, it is found 
Table 12. Regression model for learning and development.

\begin{tabular}{cccccccc}
\hline Model & \multicolumn{2}{c}{$\begin{array}{c}\text { Unstandardized } \\
\text { Coefficients }\end{array}$} & $\begin{array}{c}\text { Standardized } \\
\text { Coefficients }\end{array}$ & $\mathbf{t}$ & Sig. & $\begin{array}{c}\mathbf{R} \\
\text { Square }\end{array}$ \\
\cline { 2 - 5 } & B & Std. Error & Beta & & & & \\
\hline (Constant) & 0.763 & 0.224 & & 3.401 & 0.001 & \\
Knowledge creation & 0.044 & 0.077 & 0.041 & 0.571 & 0.568 & \\
Knowledge storage & 0.110 & 0.073 & 0.115 & 1.512 & 0.132 & 0.580 \\
Knowledge sharing & 0.408 & 0.080 & 0.409 & 5.125 & 0.000 & \\
Knowledge application & 0.251 & 0.081 & 0.278 & 3.081 & 0.002 & \\
\hline
\end{tabular}

a. Dependent variable: Learning and development.

Table 13. The correlation matrix for financial performance.

\begin{tabular}{|c|c|c|c|c|c|c|}
\hline & & 1. & 2. & 3. & 4. & 5. \\
\hline \multirow{3}{*}{$\begin{array}{l}\text { Financial } \\
\text { standards }\end{array}$} & Spearman's Correlation & 1.000 & & & & \\
\hline & Sig. (2-tailed) & & & & & \\
\hline & $\mathrm{N}$ & 176 & & & & \\
\hline \multirow{3}{*}{$\begin{array}{l}\text { Customer } \\
\text { perspectives }\end{array}$} & Spearman's Correlation & 0.130 & 1.000 & & & \\
\hline & Sig. (2-tailed) & 0.086 & & & & \\
\hline & $\mathrm{N}$ & 176 & 176 & & & \\
\hline \multirow{3}{*}{$\begin{array}{c}\text { Internal } \\
\text { operation }\end{array}$} & Spearman's Correlation & 0.147 & $0.760^{\star *}$ & 1.000 & & \\
\hline & Sig. (2-tailed) & 0.051 & 0.000 & & & \\
\hline & $\mathrm{N}$ & 176 & 176 & 176 & & \\
\hline \multirow{3}{*}{$\begin{array}{l}\text { Learning and } \\
\text { development }\end{array}$} & Spearman's Correlation & $0.200^{\star *}$ & $0.665^{\star *}$ & $0.609^{* *}$ & 1.000 & \\
\hline & Sig. (2-tailed) & 0.008 & 0.000 & 0.000 & & \\
\hline & $\mathrm{N}$ & 176 & 176 & 176 & 176 & \\
\hline \multirow{3}{*}{$\begin{array}{c}\text { Financial } \\
\text { performance }\end{array}$} & Spearman's Correlation & $0.630^{\star *}$ & 0.133 & $0.189^{*}$ & $0.190^{*}$ & 1.000 \\
\hline & Sig. (2-tailed) & 0.000 & 0.079 & 0.012 & 0.012 & \\
\hline & $\mathrm{N}$ & 176 & 176 & 176 & 176 & 176 \\
\hline
\end{tabular}

Table 14. The regression model for financial performance.

\begin{tabular}{|c|c|c|c|c|c|c|}
\hline \multirow[t]{2}{*}{ Model } & \multicolumn{2}{|c|}{$\begin{array}{l}\text { Unstandardized } \\
\text { Coefficients }\end{array}$} & \multirow{2}{*}{$\begin{array}{c}\begin{array}{c}\text { Standardized } \\
\text { Coefficients }\end{array} \\
\text { Beta }\end{array}$} & \multirow[t]{2}{*}{$\mathrm{t}$} & \multirow[t]{2}{*}{ Sig. } & \multirow{2}{*}{$\begin{array}{c}\mathbf{R} \\
\text { Square }\end{array}$} \\
\hline & B & Std. Error & & & & \\
\hline (Constant) & 0.722 & 0.361 & & 1.999 & 0.047 & \\
\hline Financial standards & 0.724 & 0.082 & 0.554 & 8.833 & 0.000 & \\
\hline Customer perspectives & -0.127 & 0.093 & -0.139 & -1.356 & 0.177 & 0.358 \\
\hline Internal operation & 0.132 & 0.092 & 0.145 & 1.435 & 0.153 & \\
\hline Learning and development & 0.097 & 0.073 & 0.112 & 1.324 & 0.187 & \\
\hline
\end{tabular}

a. Dependent variable: Financial performance. 
that there is positive significant relationship between financial standard and financial performance as $\mathrm{p}$-value is less than 0.05 . Financial performance can be explained by financial standards as p-value less than 0.05 . While, it is found that there is insignificant relationship internal operation, customer perspectives and learning and development and financial performance as p-value more than 0.05.

Based on the previous results, it can be seen that the first sub-hypothesis of the third hypothesis "there is a statistically significant relationship between the balanced scorecard and financial performance" is partially supported. Based on these results, we find that the financial standard can act as a mediator between knowledge management and financial performance because there is a direct relationship between it and financial performance.

\subsubsection{The Second Sub-Hypothesis: The Relationship between Balanced Scorecard and Non-Financial Performance}

Table 15 shows the correlation matrix for non-financial performance, it is found that that there is positive significant relationship between customer perspectives, internal operation and learning and development and non-financial performance as co-efficient equals $0.719,0.701$ and 0.595 respectively with p-value, which is less than 0.05 .

Table 16 shows the regression model for non-financial performance, it is found that there is positive significant relationship between customer perspectives and internal operation and non-financial performance as p-value is less than 0.05 . Financial performance can be explained by customer perspectives and internal operation as p-value less than 0.05 . While, it is found that there is insignificant relationship between financial standards and learning and development and non-financial performance as p-value more than 0.05 .

Table 15. The correlation matrix for non-financial performance.

\begin{tabular}{ccccccc}
\hline & & 1. & 2. & 3. & 4. & 5. \\
\hline \multirow{2}{*}{$\begin{array}{c}\text { Financial } \\
\text { standards }\end{array}$} & Spearman's Correlation & 1.000 & & & & \\
& Sig. (2-tailed) & & & & & \\
\hline \multirow{2}{*}{$\begin{array}{c}\text { Customer } \\
\text { perspectives }\end{array}$} & Spearman's Correlation & 0.130 & 1.000 & & & \\
& Sig. (2-tailed) & 0.086 & & & & \\
\hline \multirow{2}{*}{$\begin{array}{c}\text { Internal } \\
\text { operation }\end{array}$} & Spearman's Correlation & 0.147 & $0.760^{* *}$ & 1.000 & & \\
& Sig. (2-tailed) & 0.051 & 0.000 & & & \\
\hline \multirow{2}{*}{$\begin{array}{c}\text { Learning and } \\
\text { development }\end{array}$} & Spearman's Correlation & $0.200^{* *}$ & $0.665^{* *}$ & $0.609^{* *}$ & 1.000 & \\
& Sig. (2-tailed) & 0.008 & 0.000 & 0.000 & & \\
\hline \multirow{2}{*}{$\begin{array}{c}\text { Non-financial } \\
\text { performance }\end{array}$} & Spearman's Correlation & 0.087 & $0.719^{* *}$ & $0.701^{* *}$ & $0.595^{* *}$ & 1.000 \\
& Sig. (2-tailed) & 0.250 & 0.000 & 0.000 & 0.000 & \\
\hline & N & 176 & 176 & 176 & 176 & 176 \\
\hline
\end{tabular}


Table 16. The regression model for non-financial performance.

\begin{tabular}{cccccccc}
\hline \multirow{2}{*}{ Model } & \multicolumn{2}{c}{$\begin{array}{c}\text { Unstandardized } \\
\text { Coefficients }\end{array}$} & $\begin{array}{c}\text { Standardized } \\
\text { Coefficients }\end{array}$ & $\mathbf{t}$ & Sig. & $\begin{array}{c}\mathbf{R} \\
\text { Square }\end{array}$ \\
\cline { 2 - 5 } & $\mathbf{B}$ & Std. Error & Beta & & & & \\
\hline (Constant) & 1.076 & 0.322 & & & 3.347 & 0.001 & \\
Financial standards & -0.058 & 0.073 & -0.042 & -0.801 & 0.424 & \\
Customer perspectives & 0.308 & 0.083 & 0.316 & 3.708 & 0.000 & 0.557 \\
Internal operation & 0.375 & 0.082 & 0.384 & 4.572 & 0.000 & \\
Learning and development & 0.120 & 0.065 & 0.129 & 1.835 & 0.068 & \\
\hline
\end{tabular}

a. Dependent variable: Non-financial performance.

Based on the previous results, it can be seen that the first sub-hypothesis of the third hypothesis "There is a statistically significant relationship between the balanced scorecard and non-financial performance" is partially supported. Based on these results, we find that both the customer standard and the internal operations standard can play the role of mediator between knowledge management and non-financial performance because there is a direct relationship between them and the non-financial performance. Based on these results, the third hypothesis "there is a statistically significant relationship between the balanced scorecard and institutional performance" is partially supported.

\section{Conclusion, Recommendation and Limitations}

The general objective of this research is to examine whether knowledge management has an impact on institutional performance through the Balanced Scorecard, through an applied study on the Port Training Institute in Alexandria. Thus, the literature was reviewed to find out research hypotheses and to identify a search gap in the literature. Accordingly, the methodology and methodological philosophy were chosen to answer the research questions. The analysis was performed to test the effect of knowledge management on institutional performance through the Balanced Scorecard through correlation and regression analysis. The current section is a discussion of recommendations and limitations are illustrated in this chapter respectively.

\subsection{Recommendations}

The recommendations of the current research are that the research should focus on other variables that affect institutional performance. The research data was collected through a questionnaire distributed to 200 workers from the Port Training Institute in Alexandria. This research contains many recommendations that may be useful for future research. Firstly, a longitudinal study is recommended to achieve better results, as time was one of the barriers in this study. Future research could also look at other ports emerging. In addition, a larger number of the sample sizes may lead to shorter results, but this may be costly. Future research will be able to have a better timeframe to be able to collect a 
larger sample. Finally, a comparative study can be made to compare the factors that affect institutional performance in developed and developing countries.

\subsection{Limitations}

As for all researches, this research has several limitations through the study that I addressed. Firstly, despite the fact that the researcher collected data from one port, which is the port of Alexandria, the research was limited to taking into account more ports that she has. In addition, the second limitation of this research is the time limit for completing the research, which was a hindrance to collecting a larger sample size to represent the data under study. The third limitation was the small number of sample sizes used in the questionnaires collected.

\section{Acknowledgements}

I thank Allah who gave me that strength and enabled me to successfully complete this intense and hard work.

For the completion of this work, I am very grateful to my supervisor, Prof. Dr. Mohamed Wahba, Prof. Dr. Alaa El-Gharabawi and Prof. Dr. Mohamed Abdel Salam for their continued support to make this work in its final form.

Members of my committees, each of whom provided advice and guidance throughout the research process. Thank you all for your steadfast support.

\section{Conflicts of Interest}

The authors declare no conflicts of interest regarding the publication of this paper.

\section{References}

[1] Maier, R. and Hadrich, T. (2011) Knowledge Management Systems. In: Encyclopedia of Knowledge Management, 2nd Edition, IGI Global, Hershey, 779-790. https://doi.org/10.4018/978-1-59904-931-1.ch076

[2] Hong, D., Suh, E. and Koo, C. (2011) Developing Strategies for Overcoming Barriers to Knowledge Sharing Based on Conversational Knowledge Management: A Case Study of a Financial Company. Expert systems with Applications, 38, 14417-14427. https://doi.org/10.1016/j.eswa.2011.04.072

[3] Mehralian, G., Nazari, J.A., Nooriparto, G. and Rasekh, H.R. (2017) TQM and Organizational Performance Using the Balanced Scorecard Approach. International Journal of Productivity and Performance Management, 66, 111-125. https://doi.org/10.1108/IJPPM-08-2015-0114

[4] Mills, A.M. and Smith, T.A. (2011) Knowledge Management and Organizational Performance: A Decomposed View. Journal of Knowledge Management, 15, 156-171. https://doi.org/10.1108/13673271111108756

[5] Ramírez, A.M., Morales, V.J.G. and Rojas, R.M. (2011) Knowledge Creation, Organizational Learning and Their Effects on Organizational Performance. Engineering Economics, 22, No. 3. https://doi.org/10.5755/j01.ee.22.3.521

[6] Gharakhani, D. and Mousakhani, M. (2012) Knowledge Management Capabilities and SMEs' Organizational Performance. Journal of Chinese Entrepreneurship, 4, 
35-49. https://doi.org/10.1108/17561391211200920

[7] Kim, N., Im, S. and Slater, S.F. (2013) Impact of Knowledge Type and Strategic Orientation on New Product Creativity and Advantage in High-Technology Firms. Journal of Product Innovation Management, 30, 136-153. https://doi.org/10.1111/j.1540-5885.2012.00992.x

[8] Delen, D., Kuzey, C. and Uyar, A. (2013) Measuring Firm Performance Using Financial Ratios: A Decision Tree Approach. Expert Systems with Applications, 40, 3970-3983. https://doi.org/10.1016/j.eswa.2013.01.012

[9] Ha, S.-T., Lo, M.-C. and Wang, Y.-C. (2016) Relationship between Knowledge Management and Organizational Performance: A Test on SMEs in Malaysia. Procedia-Social and Behavioral Sciences, 224, 184-189.

https://doi.org/10.1016/j.sbspro.2016.05.438

[10] Sarkindaji, B.D., Hashim, N.A. and Abdullateef, A.O. (2014) Knowledge Management and Organizational Performance of Mobile Service Firms in Nigeria: A Proposed Framework. Information and Knowledge Management, 4, 88-95.

[11] El-Hassan, N., Hall, T., Tulunay, I. and Ziveyi, J. (2015) Performance of a Balanced Portfolio with Active Covered-Call Strategies. Working Paper, Submitted for Publication, School of Finance and Economics, University of Technology, Sydney.

[12] Dickel, D.G. and de Moura, G.L. (2016) Organizational Performance Evaluation in Intangible Criteria: A Model Based on Knowledge Management and Innovation Management. RAI Revista de Administração e Inovação, 13, 211-220.

https://doi.org/10.1016/j.rai.2016.06.005

[13] Inkinen, H. (2016) Review of Empirical Research on Knowledge Management Practices and Firm Performance. Journal of Knowledge Management, 20, 230-257. https://doi.org/10.1108/JKM-09-2015-0336

[14] Alaarj, S., Abidin-Mohamed, Z. and Bustamam, U.S.B.A. (2016) Mediating Role of trust on the Effects of Knowledge Management Capabilities on Organizational Performance. Procedia-Social and Behavioral Sciences, 235, 729-738. https://doi.org/10.1016/j.sbspro.2016.11.074

[15] Theriou, N.G., Maditinos, D. and Theriou, G. (2011) Knowledge Management Enabler Factors and Firm Performance: An Empirical Research of the Greek Medium and Large Firms. European Research Studies Journal, XIV, 97-134 https://doi.org/10.35808/ersj/321

[16] Alegre, J., Sengupta, K. and Lapiedra, R. (2013) Knowledge Management and Innovation Performance in a High-Tech SMEs Industry. International Small Business Journal, 31, 454-470. https://doi.org/10.1177/0266242611417472

[17] Jelenic, D. (2011) The Importance of Knowledge Management in Organizations-With Emphasis on the Balanced Scorecard Learning and Growth Perspective. In Management, Knowledge and Learning, International Conference.

[18] Valmohammadi, C. and Ahmadi, M. (2015) The Impact of Knowledge Management Practices on Organizational Performance. Journal of Enterprise Information Management, 28, 131-159. https://doi.org/10.1108/JEIM-09-2013-0066

[19] Gonzalez-Padron, T.L., Chabowski, B.R., Hult, G.T.M. and Ketchen Jr., D.J. (2010) Knowledge Management and Balanced Scorecard Outcomes: Exploring The Importance of Interpretation, Learning and Internationality. British Journal of Management, 21, 967-982. https://doi.org/10.1111/j.1467-8551.2009.00634.x

[20] Wang, C.-H., Lu, I.-Y. and Chen, C.-B. (2010) Integrating Hierarchical Balanced Scorecard with Non-Additive Fuzzy Integral for Evaluating High Technology Firm Performance. International Journal of Production Economics, 128, 413-426. 
https://doi.org/10.1016/j.ijpe.2010.07.042

[21] Al-Najjar, S.M. and Kalaf, K.H. (2012) Designing a Balanced Scorecard to Measure a Bank's Performance: A Case Study. International Journal of Business Administration, 3, 44. https://doi.org/10.5430/ijba.v3n4p44

[22] Malagueño, R., Lopez-Valeiras, E. and Gomez-Conde, J. (2018) Balanced Scorecard in SMEs: Effects on Innovation and Financial Performance. Small Business Economics, 51, 221-244. https://doi.org/10.1007/s11187-017-9921-3

[23] Yunus, N.K. and Rashid, M.S. (2019) The Role of Knowledge Management to Enhancing Public Services in Dubai. European Journal of Interdisciplinary Studies, 5, 64. https://doi.org/10.26417/ejis.v5i1.p64-70

[24] Al-Hosaini, F.F. and Sofian, S. (2015) A Review of Balanced Scorecard Framework in Higher Education Institution (HEIs). International Review of Management and Marketing, 5, 26-35. 